\title{
Monitoring the expression of purinoceptors and nucleotide- metabolizing ecto-enzymes with antibodies directed against proteins in native conformation
}

\author{
Sina Möller • Caroline Jung • Sahil Adriouch • \\ Gudrun Dubberke • Fabienne Seyfried • \\ Michel Seman • Friedrich Haag • Friedrich Koch-Nolte
}

Received: 31 July 2007 / Accepted: 17 September 2007 / Published online: 6 October 2007

(C) Springer Science + Business Media B.V. 2007

\begin{abstract}
Following their release from cells, ATP and $\mathrm{NAD}$, the universal currencies of energy metabolism, function as extracellular signalling molecules. Mammalian cells express numerous purinoceptors, i.e., the nucleotidegated P2X ion channels and the G-protein-coupled P2Y receptors. Signalling through purinoceptors is controlled by nucleotide-metabolizing ecto-enzymes, which regulate the availability of extracellular nucleotides. These enzymes include ecto-nucleoside triphosphate diphosphohydrolases (ENTPD, CD39 family) and ecto-nucleotide pyrophosphatase/ phosphodiesterases (ENPP, CD203 family). Investigation of these receptors and enzymes has been hampered by the lack of available antibodies, especially ones that recognize these proteins in their native conformation. This study reports the use of genetic immunization to generate such antibodies against $\mathrm{P} 2 \mathrm{X}_{1}, \mathrm{P} 2 \mathrm{X}_{4}, \mathrm{P} 2 \mathrm{X}_{7}$, ENTPD1, ENPTD2, ENPTD5, ENPTD6, ENPP2, ENPP3, ENPP4, ENPP5, and ENPP6. Genetic immunization ensures expression of the native protein by the cells of the immunized animal and yields antibodies directed against proteins in native conformation
\end{abstract}

Friedrich Haag and Friedrich Koch-Nolte share senior authorship.

Sina Möller and Caroline Jung contributed equally to this study.

S. Möller $\cdot$ C. Jung $\cdot$ S. Adriouch $\cdot$ G. Dubberke $\cdot$ F. Seyfried $\cdot$

F. Haag $(\bowtie) \cdot$ F. Koch-Nolte

Institute of Immunology, Hamburg University Medical Center,

Campus Forschung 2.OG; Rm. 02.059, Martinistr. 52,

20246 Hamburg, Germany

e-mail: haag@uke.uni-hamburg.de

S. Adriouch $\cdot$ M. Seman $\cdot$ F. Haag $\cdot$ F. Koch-Nolte INSERM U519,

Rouen, France
(ADAPINCs). Such antibodies are especially useful for immunofluorescence and immunoprecipitation analyses, whereas antibodies against synthetic peptides usually function well only in Western-blot analyses. Here we illustrate the utility of the new antibodies to monitor the cell surface expression of and to purify some key players of purinergic signalling.

Keywords Monoclonal antibodies · Purinoceptor .

Ecto-nucleotidases · Genetic immunization

\begin{tabular}{|c|c|}
\hline \multicolumn{2}{|c|}{ Abbreviations } \\
\hline ADAPINCs & $\begin{array}{l}\text { Antibodies directed } a \text { gainst proteins in native } \\
\text { conformation }\end{array}$ \\
\hline AEBSF & $\begin{array}{l}\text { 4-(2-Aminoethyl) benzenesulfonyl fluoride } \\
\text { hydrochloride }\end{array}$ \\
\hline ATP & Adenosine triphosphate \\
\hline ENPP & $\begin{array}{l}\text { Ecto-nucleotide pyrophosphatase/ } \\
\text { phosphodiesterase }\end{array}$ \\
\hline ENTPD & $\begin{array}{l}\text { Ecto-nucleoside triphosphate diphosphohy- } \\
\text { drolase }\end{array}$ \\
\hline NAD & Nicotinamide adenine dinucleotide \\
\hline $\mathrm{PO}$ & Peroxidase \\
\hline PVDF & Polyvinylidene difluoride \\
\hline
\end{tabular}

\section{Introduction}

Following their release from cells, the universal currencies of energy metabolism, ATP and NAD, function as extracellular signalling molecules [1-5]. Molecular cloning has identified 7 nucleotide-gated ion channels (P2X purinoceptors) and $>8$ nucleotide-activated G-protein-coupled receptors (P2Y purinoceptors) [6-10]. Signaling through 
purinoceptors is effectively controlled by nucleotidemetabolizing ecto-enzymes, which regulate the availability of extracellular nucleotides [11]. Prominent roles are played by members of two families of ecto-enzymes: the ectonucleoside triphosphate diphosphohydrolases (ENTPD, CD39 family) [12] and the ecto-nucleotide pyrophosphatase/ phosphodiesterases (ENPP, CD203 family) [13].

The mammalian P2X family encompasses seven members. All P2X purinoceptors contain cytosolic $\mathrm{N}$ - and C-terminal tails, two membrane spanning domains, and an extracellular domain of approximately 280 amino acids containing the ligand-binding site and 10 conserved cysteine residues that likely form five intrachain disulfide bonds [14, 15]. The extracellular domains of the respective mouse and human P2X orthologues show high (ca. 80-90\%) sequence identity; the paralogues within a given species show lower $(40-50 \%)$ identity.

The mammalian ENTPD family encompasses eight members [16]. ENTPD1-4, 7 and 8 have a structure similar to that of $\mathrm{P} 2 \mathrm{X}$ purinoceptors, i.e., cytosolic $\mathrm{N}$ - and Cterminal tails, two transmembrane spanning domains, and an extracellular domain of approximately 440 amino acids, encompassing the ligand-binding site and four conserved cysteines likely engaged in intrachain disulfide bridges [12]. ENTPD1-3 and 8 are expressed as cell surface enzymes, ENTPD4 and ENTPD7 as luminal enzymes of intracellular organelles. ENTPDases share structural similarities with the actin/HSP70/sugar kinase superfamily [12]. ENTPD5 and ENTPD6 lack the second transmembrane region. Moreover, in ENTPD5, the region corresponding to the first transmembrane domain of the other family members is N-terminal and functions as a signal peptide, resulting in the secretion of ENTPD5 into the lumen of the endoplasmic reticulum. ENTPD6 is a type II transmembrane protein. ENTPD orthologues show high (ca. 80-90\%) sequence identity; the paralogues within a given species show lower (30-50\%) identity.

The ENPP family encompasses seven members [13]. ENPP1-3 are type II transmembrane proteins with a structure analogous to that of ENTPD6, i.e., an N-terminal cytosolic tail, a single transmembrane domain and an extracellular catalytic domain of approximately 400 amino acids. ENPP4-7, in contrast, are type I membrane proteins. A hydrophobic N-terminus acts as a signal peptide, the extracellular catalytic domain is followed by a single transmembrane domain and a short C-terminal cytosolic tail. ENPPs 4-7 consist of catalytic domains only, the catalytic domains of ENPPs 1-3 are flanked by genetically fused upstream somatomedin B and downstream nucleaselike domains [13]. ENPPs share structural similarities with the alkaline-phosphatase superfamily [17, 18]. The catalytic domain of ENPP orthologues shows high (ca. 80-90\%) sequence identity; the paralogues within a given species show lower (40-50\%) identity.

Despite their relevance for purinergic signalling, investigation of these receptors and enzymes has been hampered by the lack of available antibodies, especially ones that recognize the enzymes in their native conformation. Antibodies raised by immunization with synthetic peptides derived from the known amino acid sequence of a protein of interest generally work well in Western-blot analyses but often fail to recognize the native protein on the cell surface (Fig. 1). Such antibodies can be used successfully for monitoring the overall expression level of the protein of interest in a population of cells but cannot be used to assess cell surface expression on individual cells. Genetic immunization, in contrast, ensures that the protein of interest is expressed in native conformation by the cells of the
Fig. 1 DNA immunization vs. peptide immunization

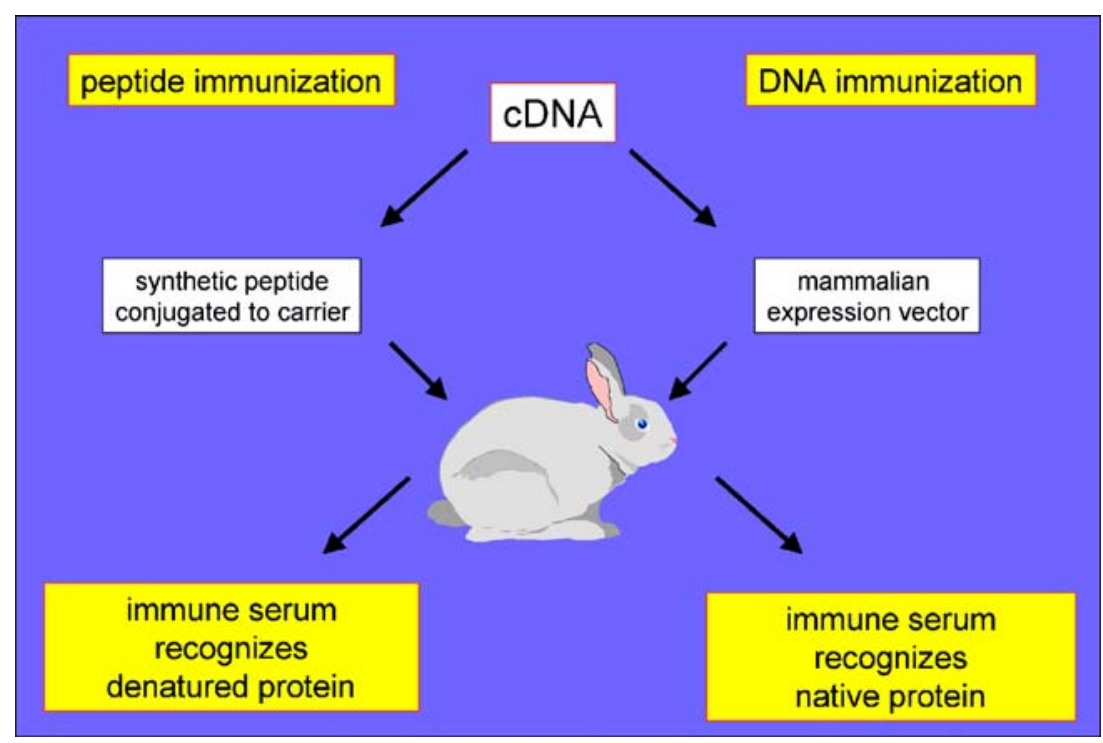


immunized animal and yields antibodies directed against proteins in native conformation (ADAPINCs) [19, 20]. Such antibodies function well in immunofluorescence, FACS, ELISA, and immunoprecipitation analyses, i.e., assays in which antipeptide antibodies often fail. We have previously employed this technique to generate highly specific polyclonal and monoclonal antibodies against ectoADP-ribsoyltransferases and against murine P2X $\mathrm{X}_{7}$ [20-23]. Here we report the generation and characterization of similar antibodies against other key players of purinergic signalling and illustrate the utility of these antibodies for monitoring the cell surface expression of their cognate antigens.

\section{Materials and methods}

Cloning of expression vectors and cell transfections

Clones encoding full-length open-reading frames representing members of the P2X, ENTPD, and ENPP families were purchased from the mammalian genome collection (www. rzpd.de). Clones that were not already in an expression vector (pCMV-SPORT6) were subcloned into the pCDNA6 expression vector. Further expression constructs were kindly provided by James Wiley, Sydney (human $\mathrm{P} 2 \mathrm{X}_{7}$ ), Richard J. Evans, Leicester (human P2X 1 ), François Rassendren, Montpellier (mouse $\mathrm{P} 2 \mathrm{X}_{4}$ ), Ruth MurrellLagnado, Cambridge (rat $\mathrm{P} 2 \mathrm{X}_{4}$ ), and Astrid Kehlen, Halle (hENPP2). An expression construct for nuclear green fluorescent protein was generated by cloning the DNAbinding domain of the LKLF transcription factor [24] as a C-terminal fusion protein into the pEGFP-N1 vector (Clontech). Expression constructs were transfected into $\mathrm{CHO}$ and HEK cells (5 $\mathrm{\mu g}$ for purinoceptors and ectoenzymes and/or $0.5 \mu \mathrm{g}$ eGFP-LKLF per T25 flask containing $2 \times 10^{6}$ cells) with the JetPei transfection reagent (Q-Biogen). For stable transfections, plasmids were linearized with $S s p 1$ or $S c a 1$ before transfection, and stable transfectants were selected by cultivating cells in the presence of $12 \mu \mathrm{g} / \mathrm{ml}$ blasticidin (Sigma).

Genetic immunization and purification of antibodies

Genetic immunizations were performed as described [20, 22]. In brief, rabbits or rats were immunized four times by ballistic DNA immunization with plasmid-conjugated gold particles. Serum samples were obtained 10 days postimmunization. For monoclonal antibody production, animals received a final boost with transiently transfected HEK cells $\left(2 \times 10^{6}\right.$ cells in $200 \mu \mathrm{l}$ PBS i.v. $) 3$ days prior to sacrifice. Splenocytes were fused to $\mathrm{Sp} 2 / 0$ myeloma cells and screened for production of specific antibodies by immunofluorescence analysis of $\mathrm{CHO}$ cells that had been co-transfected 20-42 h earlier with constructs encoding eGFP-LKLF and the protein of interest. Antibodies were purified by affinity chromatography on Protein G Sepharose (Pharmacia), and conjugated to Alexa488 according to the manufacturer's (Molecular Probes) instructions. Antibodies directed against the C-terminal peptides of $\mathrm{P} 2 \mathrm{X}$ purinoceptors were purchased from Caltag (rat P2X 1 , Cal), ABCAM (rat $\mathrm{P} 2 \mathrm{X}_{4}, \mathrm{Abc}$ ), and Alomone (mouse $\mathrm{P} 2 \mathrm{X}_{7}, \mathrm{Al}$ ). The L4 anti-human P2X7 mAb was kindly provided by Dr. Ian Chessel at Glaxo Wellcome (Middlesex, UK).

Immunofluorescence analyses

CHO cells were co-transfected with expression constructs for purinoceptors or ecto-enzymes and nuclear GFP (5 and $0.5 \mu \mathrm{g} / 10^{6}$ cells, respectively). Cells were transferred onto 96-well plates $\left(4 \times 10^{5}\right.$ cells/well $) 6 \mathrm{~h}$ post-transfection. Then, $20 \mathrm{~h}$ after transfection, cells were fixed for $10 \mathrm{~min}$ in $2 \%$ paraformaldehyde (PFA) and then stained with serial dilutions of immune serum for $30 \mathrm{~min}$ at room temperature. To detect ENTPD5, which is not bound to the cell surface, cells were fixed in 4\% PFA and subsequently permeabilized with $0.5 \%$ IGEPAL (Sigma) before staining. Bound antibody was detected with PE-conjugated antirat or antirabbit IgG (1:100) (Dianova). Cell nuclei were counterstained with Hoechst 33342. Cells were analyzed with a Zeiss Axiovert 25 microscope equipped with the Canon PowerShot G2 digital camera and appropriate filters for visualizing Hoechst stain (Zeiss filter set 01), green fluorescent protein (Zeiss filter set 10) and PE fluorochrome (Zeiss filter set 15). Photographs were taken at $40 \times$ magnification with fixed camera settings (digital zoom: 4.3×, aperture: 5.0, exposure time: $2 \mathrm{~s}$ for GFP and PE, $1 / 8 \mathrm{~s}$ for Hoechst 33342). GFP and PE images were merged using Adobe Photoshop software.

\section{FACS analyses}

For FACS analyses, cells were harvested by brief trypsinization (5 $\mathrm{min}$ at room temperature) and washed in serumcontaining medium. Cells $\left(5 \times 10^{5} / 100 \mu \mathrm{l}\right)$ were stained either directly with Alexa-488-conjugated antibodies $(1 \mu \mathrm{g})$ or with serially diluted immune serum followed by PEconjugated antirat or antirabbit $\operatorname{IgG}(1: 100$, Dianova). Gating was performed on living cells on the basis of propidium iodide exclusion.

Immunoprecipitation analyses

Antibodies were conjugated to Protein G Sepharose beads (Pharmacia) $(1 \mu \mathrm{g}$ antibody $/ 20 \mu \mathrm{L}$ beads in $200 \mu \mathrm{L}$ PBS containing 1\% Triton $\mathrm{X}-100$ ) by incubation on a roller for $30 \mathrm{~min}$ at room temperature. Beads were washed twice in $\mathrm{PBS} / 1 \%$ 
Triton X-100 before use for immunoprecipitation. Cells $\left(10^{7} / \mathrm{ml}\right)$ were lysed in PBS, $1 \%$ Triton-X100, $1 \mathrm{mM}$ AEBSF (Sigma) for $20 \mathrm{~min}$ at $4^{\circ} \mathrm{C}$. Insoluble material was pelleted by centrifugation, and the cleared lysates $\left(2 \times 10^{6}\right.$ cells in $\left.200 \mu \mathrm{L}\right)$ were subjected to immunoprecipitation using $20 \mu \mathrm{L}$ antibodyconjugated beads by incubation on a roller for $30 \mathrm{~min}$ at room temperature. Beads were washed four times in $\mathrm{PBS} / 1 \%$ Triton $\mathrm{X}-100$. Proteins were eluted from the beads by incubation in SDS-PAGE sample buffer for $15 \mathrm{~min}$ at $70^{\circ} \mathrm{C}$. Eluted proteins were size-fractionated on precast SDS-PAGE gels (Invitrogen) and blotted onto PVDF membranes. Purinoceptors and ectoenzymes were detected with serially diluted serum followed by peroxidase (PO)-conjugated antirabbit $\operatorname{IgG}(1: 5,000)$ using the ECL system (Amersham).

Immunoblot analyses

Cells $\left(10^{7} / \mathrm{ml}\right)$ were pelleted by centrifugation and lysed by resuspension in SDS-PAGE sample buffer (Invitrogen). DNA was sheared by brief ultrasonication on ice (two 15-s pulses with an MSE ultrasonicator at maximum power setting). Insoluble material was pelleted by centrifugation, and soluble proteins $\left(5 \times 10^{5}\right.$ cell equivalents/lane) were size-fractionated on precast SDS-PAGE gels (Invitrogen) under reducing conditions and blotted onto PVDF membranes. Purinoceptors and ecto-enzymes were detected with serially diluted serum followed by PO-conjugated antirabbit $\operatorname{IgG}(1: 5,000)$ using the ECL system (Amersham).

\section{Results and discussion}

Use of transiently transfected $\mathrm{CHO}$ cells to assess the specificity and titres of antisera against purinoceptors and ecto-enzymes

Antibodies raised by genetic immunization of rabbits and rats with cDNA expression constructs for purinoceptors, ENTPDs, and ENPPs were assayed for reactivity and specificity by indirect immunofluorescence staining of CHO cells, $24 \mathrm{~h}$ after cotransfection with a construct encoding nuclear GFP and the cDNA expression construct used for immunization (Fig. 2 and Table 1). By this time, transfected cells were clearly distinguishable from untransfected cells by virtue of their green fluorescent nuclei (Fig. 2). Specific antibodies were detected on the basis of bright cell surface staining of transfected cells and lack of reactivity with untransfected cells. Antipeptide antisera against the same antigens, in contrast, did not show any detectable reactivity in this assay (Table 1).

Monitoring cell surface expression of purinoceptors and ecto-enzymes by flow cytometry

The utility of the ADAPINC antisera for monitoring cell surface expression was assessed further by flow cytometry (FACS analyses) of transiently transfected HEK cells (Fig. 3). The results confirm that the antisera react a

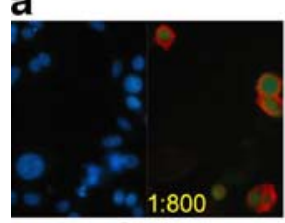

$9316 \alpha-\mathrm{hP} 2 \mathrm{X} 1$

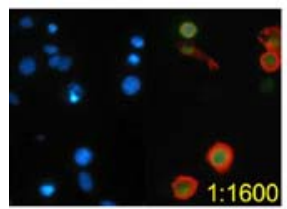

$\mathrm{CR} 29 \alpha-\mathrm{mhP} 2 \mathrm{X} 4$

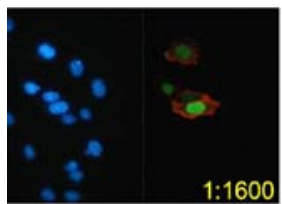

$3428 \alpha-\mathrm{rP} 2 \mathrm{X} 7$

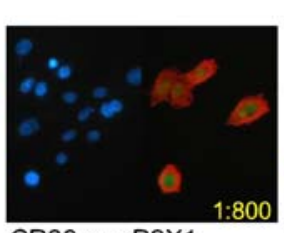

$\mathrm{CR} 30 \alpha-\mathrm{mP} 2 \mathrm{X} 1$

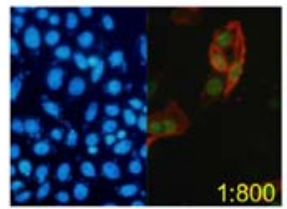

$116 \alpha-\mathrm{mP} 2 \mathrm{X} 4$

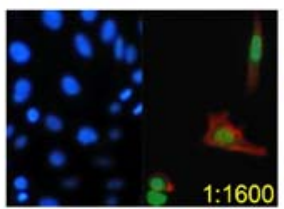

$\mathrm{K} 1 \mathrm{G} \alpha-\mathrm{mP} 2 \mathrm{X} 7$

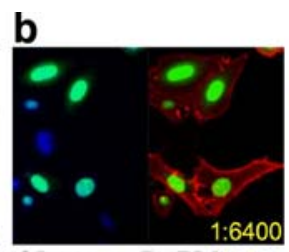

CR44 $\alpha$-mENTPD1

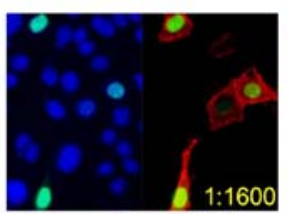

CR45 $\alpha$-mENTPD2

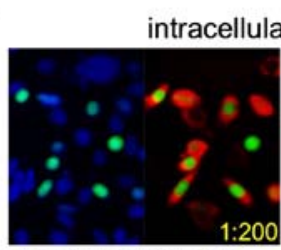

CR47 $\alpha$-mENTPD5

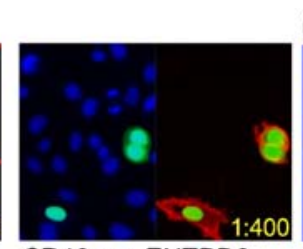

CR46 $\alpha$-mENTPD6

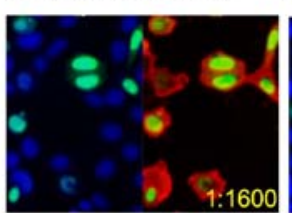

$5441 \alpha$-hENTPD2

r staining

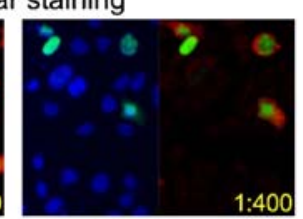

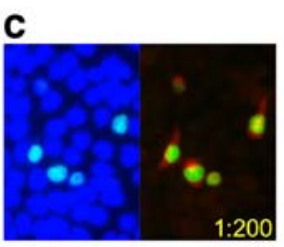

K2G $\alpha$-hENPP2 (ATX)

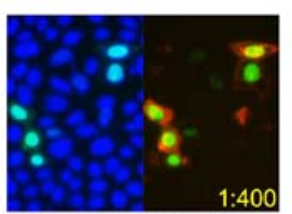

CR66 $\alpha$-mENPP5

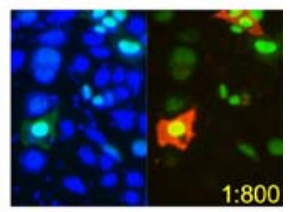

CR65 $\alpha$-mENPP4

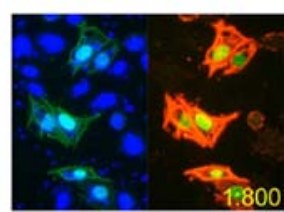

CR67 $\alpha$-mENPP6

Fig. 2 Immunofluorescence analyses of $\mathrm{CHO}$ cells following transient cotransfection with expression constructs for nuclear green fluorescent protein (GFP) and purinoceptors (a), CD39-like ENTPDs (b), and CD203-like ENPPs (c). CHO cells were cotransfected with nuclear GFP and expression constructs for the indicated purinoceptors or ecto-enzymes. Twenty hours after transfection, cells were stained with serial dilutions of the indicated antisera followed by PE-

conjugated antirabbit IgG. To detect non-membrane-bound ENTPD5, intracellular staining was performed by fixing and permeabilizing cells. Cell nuclei were counterstained with Hoechst 33342. Cells were analyzed with a Zeiss Axiovert 25 microscope equipped with filters for visualizing Hoechst dye, GFP, and PE fluorochrome. Panels show merged images for Hoechst dye and GFP (b, c, left panels) or for GFP and PE (a-c, right panels) 
Table 1 Titres, specificities, and applications of antibodies against members of the families of P2X purinoceptors, CD39-like ENTPDs, and CD203-like ENPPs

\begin{tabular}{|c|c|c|c|c|c|}
\hline Antibody & Host & Titre & Specificity & $\begin{array}{l}\text { FACS/ } \\
\text { IFT }\end{array}$ & $\begin{array}{l}\text { Western } \\
\text { blot }\end{array}$ \\
\hline \multicolumn{6}{|l|}{ P2X family } \\
\hline 9316 & $\mathrm{rb}$ & $1: 800$ & $\mathrm{hP} 2 \mathrm{X}_{1}$ & +++ & $(+)$ \\
\hline RG2 & $\mathrm{rt}$ & $1: 800$ & $\mathrm{hP} 2 \mathrm{X}_{1}$ & +++ & ++ \\
\hline CR29 & $\mathrm{rb}$ & $1: 1600$ & $\mathrm{hP} 2 \mathrm{X}_{4}$ & +++ & ++ \\
\hline CR30 & $\mathrm{rb}$ & $1: 1600$ & $\mathrm{mP} 2 \mathrm{X}_{1}$ & +++ & ++ \\
\hline 116 & $\mathrm{rb}$ & $1: 800$ & $\mathrm{mP} 2 \mathrm{X}_{4}$ & & \\
\hline RG22 & $\mathrm{rt}$ & $1: 1600$ & $\mathrm{mP} \mathrm{X}_{4}$ & +++ & +++ \\
\hline $\mathrm{K} 1 \mathrm{G}$ & $\mathrm{rb}$ & $1: 1600$ & $\mathrm{mP} 2 \mathrm{X}_{7}$ & +++ & - \\
\hline RH23 & $\mathrm{rt}$ & $1: 1600$ & $\mathrm{mP} 2 \mathrm{X}_{7}$ & ++ & - \\
\hline Hano43 & $\mathrm{rt}$ & $\mathrm{mAb}$ & $\mathrm{mP} 2 \mathrm{X}_{7}$ & ++ & - \\
\hline 3428 & $\mathrm{rb}$ & $1: 1600$ & $\mathrm{rP}_{2} \mathrm{X}_{7}$ & ++ & - \\
\hline Calt & $\mathrm{rb}$ & $1: 2000$ & $\mathrm{rP} 2 \mathrm{X}_{1}$ & - & +++ \\
\hline $\mathrm{Abc}$ & $\mathrm{rb}$ & $1: 2000$ & $\mathrm{rP} 2 \mathrm{X}_{4}$ & - & +++ \\
\hline $\mathrm{Al}$ & $\mathrm{rb}$ & $1: 5000$ & $\mathrm{mP} 2 \mathrm{X} 7$ & - & +++ \\
\hline \multicolumn{6}{|c|}{ ENTPD family } \\
\hline 5441 & $\mathrm{rb}$ & $1: 1600$ & hENTPD2 & +++ & - \\
\hline RG10 & $\mathrm{rt}$ & $1: 1000$ & h/mENTPD2 & +++ & nd \\
\hline RG10-B28 & $\mathrm{rt}$ & $\mathrm{mAb}$ & hENTPD2 & +++ & nd \\
\hline 5446 & $\mathrm{rb}$ & 1: 400 & hENTPD5 & +++ & - \\
\hline CR44 & $\mathrm{rb}$ & $1: 6400$ & mENTPD1 & +++ & +++ \\
\hline RG9 & $\mathrm{rt}$ & $1: 1600$ & mENTPD1 & +++ & nd \\
\hline RG9-A59 & $\mathrm{rt}$ & $\mathrm{mAb}$ & mENTPD1 & +++ & - \\
\hline CR45 & $\mathrm{rb}$ & $1: 1600$ & mENTPD2 & +++ & + \\
\hline CR63 & $\mathrm{rb}$ & $1: 1600$ & mETNTPD2 & +++ & nd \\
\hline CR46 & $\mathrm{rb}$ & $1: 400$ & mENTPD5 & +++ & - \\
\hline CR47 & $\mathrm{rb}$ & $1: 200$ & mENTPD6 & +++ & - \\
\hline \multicolumn{6}{|c|}{ ENPP family } \\
\hline $\mathrm{K} 2 \mathrm{G}$ & $\mathrm{rb}$ & $1: 200$ & hENPP2 & +++ & nd \\
\hline 7619 & $\mathrm{rb}$ & $1: 800$ & hENPP2 & +++ & nd \\
\hline CR65 & $\mathrm{rb}$ & $1: 800$ & mENPP4 & +++ & nd \\
\hline CR66 & $\mathrm{rb}$ & $1: 400$ & mENPP5 & +++ & nd \\
\hline CR67 & $\mathrm{rb}$ & $1: 800$ & mENPP6 & +++ & nd \\
\hline 7620 & $\mathrm{rb}$ & $1: 3200$ & rENPP3 & +++ & nd \\
\hline
\end{tabular}

specifically with appropriately transfected cells and that they do not react with untransfected HEK cells. Importantly, the antisera recognize the respective purinoceptor/ ecto-enzyme on the cell surface of living cells. In contrast, antipeptide antisera against the same antigens did not show any detectable reactivity with the transfected cells in these assays. Further, the use of the ADAPINC antisera for FACS

Fig. 3 FACS analyses of purinoceptor (a) and ecto-enzyme (b) expression by transfected HEK cells. HEK cells were transfected with expression constructs for the indicated purinoceptors and ecto-enzymes. Then, $24 \mathrm{~h}$ post-transfection, cells were harvested by brief trypsinization and single cell suspensions were stained with serial dilutions of the indicated antisera followed by PE-conjugated antirabbit IgG before FACS analyses. Control stainings were performed with untransfected cells (shaded histograms in $\mathbf{a}$, dotted lines in $\mathbf{b}$ ) and with cells transfected with the species orthologue (red lines in a) analyses permits an assessment of the relative expression level of the cognate protein on the cell surface of individual cells as well as an assessment of the number of transfected vs. untransfected cells in the cell population. These

$\begin{array}{lllllll}\text { a } & \operatorname{mP} 2 \times 1 & h P 2 X 1 & \operatorname{mP} 2 \times 4 & h P 2 \times 4 & \operatorname{mP} 2 \times 7 & \text { rP2X7 }\end{array}$

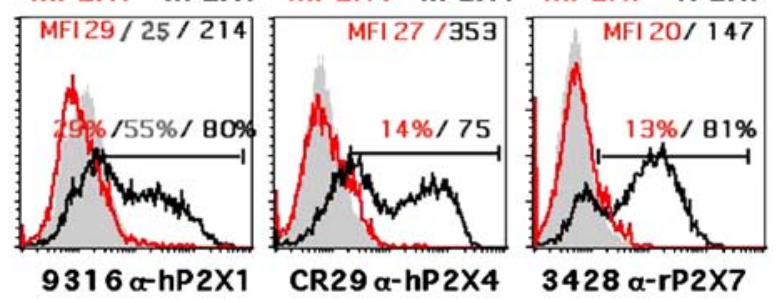

$\begin{array}{llllll}\text { hP2X1 } & \text { mP2X1 } & \text { hP2X4 } & \text { mP2X4 } & \text { rP2X7 } & \text { mP2X7 }\end{array}$

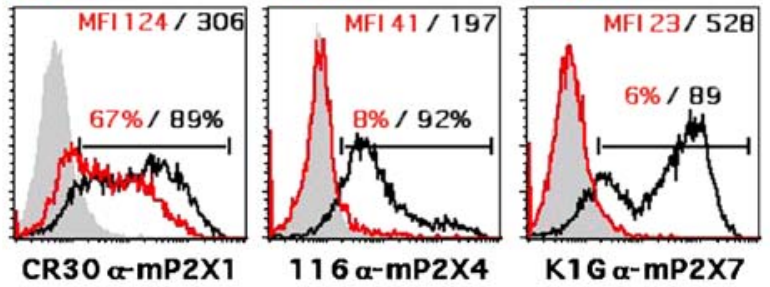

$\begin{array}{llllll}\mathrm{rP} 2 X 7 & \mathrm{mP} 2 X 7 & \mathrm{rP} 2 X 7 & \text { hP2X7 } & \operatorname{mP} 2 X 7 & \text { hP2X7 }\end{array}$

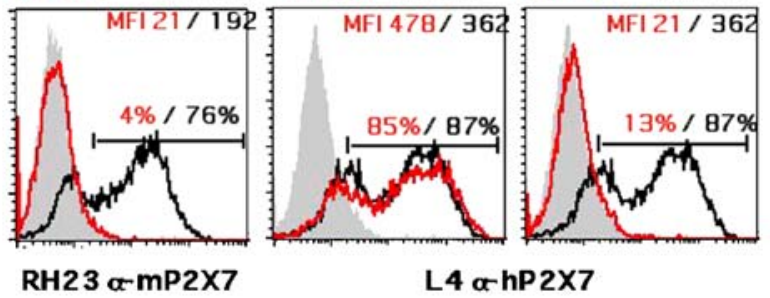

RH23 $\%$ mP2X7

L4 o-hP2X7 b
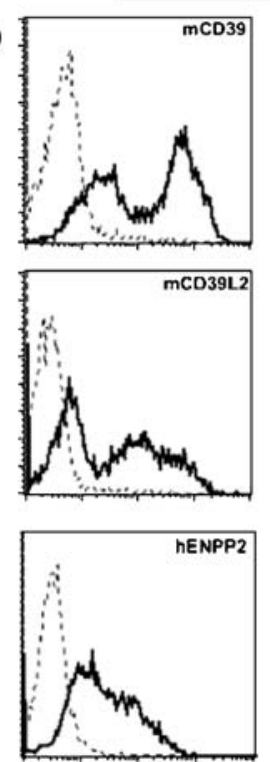

untransfectedHEK cells transfectedHEK cells orthologue-transfected
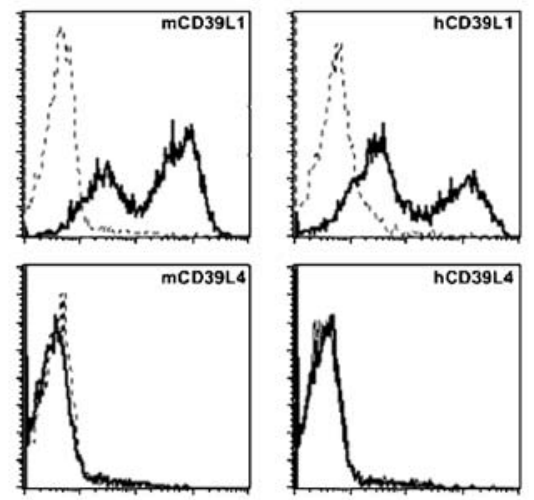

transiently transfected HEK.T-cells

- - - PIS 1:100

IS 1:100 
parameters cannot be quantified appropriately by Westernblot analyses, since for these analyses, lysates are prepared from cell populations. We further used the FACS-based assay system to test whether the antisera crossreact with other members (paralogues) of the receptor/enzyme family and/or the same receptor/enzyme (orthologue) in other species (human, rat, or mouse). The results reveal that most antisera are specific for the receptor/enzyme used for immunization and do not cross-react with other members of the same protein family. Some antisera, however, did react with the orthologous protein, in particular at low dilutions, e.g., antiserum $\mathrm{CR} 30$ raised against mouse $\mathrm{P} 2 \mathrm{X}_{1}$

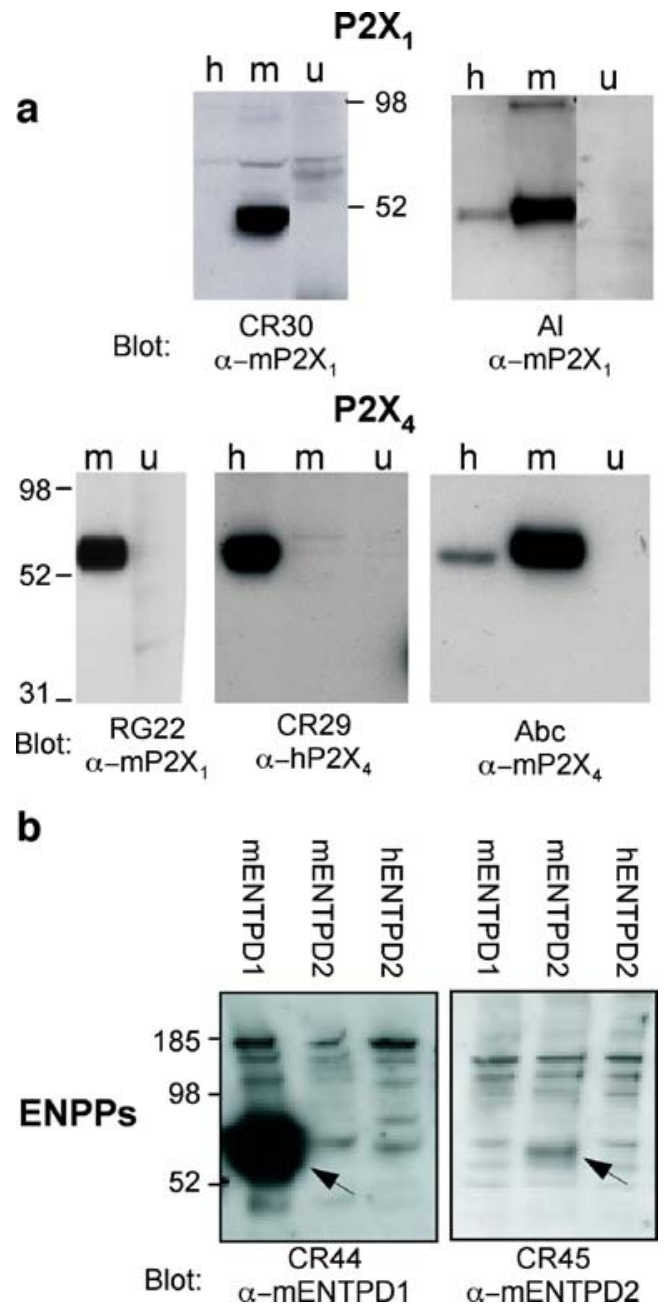

Fig. 4 Immunoblot analyses of purinoceptor (a) and ecto-enzyme (b) expression by transfected HEK cells. Untransfected $(u)$ or HEK cells transfected with mouse $(m)$ or human $(h)$ purinoceptors or ectoenzymes were solubilized $24 \mathrm{~h}$ post-transfection with SDS-PAGE sample buffer. Proteins in cell lysates were size-fractionated by SDSPAGE and subjected to immunoblot analyses using the indicated antisera. Bound antibodies were detected with peroxidase-conjugated secondary antibody and the ECL system shows some reactivity with the human $\mathrm{P} 2 \mathrm{X}_{1}$ orthologue (Fig. 3a).

Some of the antisera recognize the denatured cognate antigen in Western-blot analyses

We next tested the utility of the ADAPINC antisera for monitoring overall protein expression levels in immunoblot analyses (Fig. 4). To this end, we size-fractionated the proteins from lysates of untransfected and of transiently transfected HEK cells by SDS-PAGE followed by immunoblot analyses. The results show that only some of the ADAPINC antisera detected bands of the expected size. For comparison, we again performed parallel analyses with antisera raised against the same proteins by peptide immunization. The results show that the antipeptide sera generally detected bands of the expected size. The $\mathrm{C}$-terminal peptide is commonly used for peptide immunization. In the case of $\mathrm{P} 2 \mathrm{X}_{7}$, this sequence is highly conserved between rat, mouse and human orthologues, and the corresponding antipeptide serum recognized the respective orthologues (not shown). In contrast, in the case of $\mathrm{P}_{2} \mathrm{X}_{4}$, the mouse and human
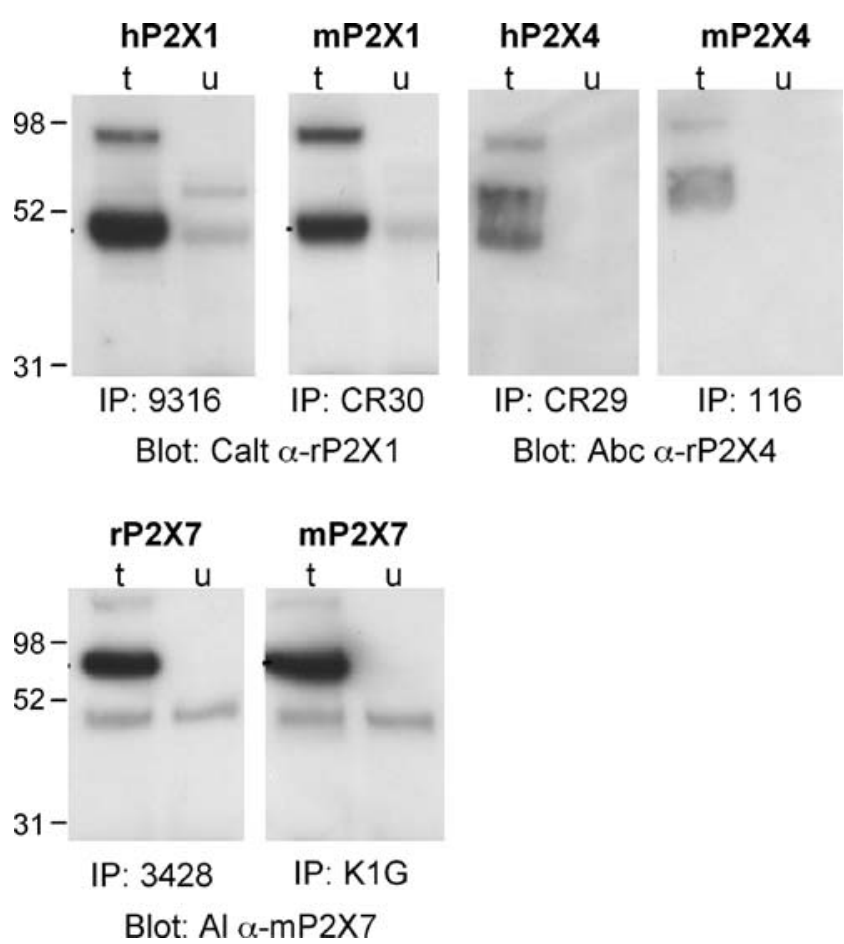

Fig. 5 Immunoprecipitation of purinoceptors by antibodies raised via genetic immunization. Untransfected $(u)$ and transfected $(t)$ HEK cells were solubilized $24 \mathrm{~h}$ post-transfection with $\mathrm{PBS} / 1 \%$ Triton X-100. Purinoceptors were immunoprecipitated from cell lysates by incubation with the indicated antisera bound to Protein G Sepharose. Precipitates were subjected to immunoblot analysis as in Fig. 4, using the indicated antipeptide antisera for detection 
sequences differ in two and five positions, respectively, from the rat peptide used for immunization, and this antipeptide serum shows only weak cross-reactivity with these orthologues (Fig. 4a, Abc $\alpha$-mP2X4).

\section{Affinity purification of purinoceptors and ecto-enzymes}

Finally, we tested the utility of the ADAPINC antisera for immunoprecipitation of the cognate proteins from cell lysates (Fig. 5). To this end, we prepared lysates of untransfected and of transiently transfected HEK using the nondenaturing nonionic detergent Triton-X-100. Lysates were incubated with ADAPINC antibodies immobilized on protein-G sepharaose beads, and proteins bound to washed beads were subsequently analyzed by SDS-PAGE followed by immunoblot analyses with antipeptide antibodies. The results show that all of the ADAPINC antisera efficiently precipitated proteins of the expected size from cell lysates. This underscores the utility of these antibodies for purifying native receptors and ecto-enzymes from lysed cells.

\section{Conclusion}

Using genetic immunization, we have raised highly specific polyclonal and monoclonal antibodies against key players of purinergic signalling, i.e., $\mathrm{P} 2 \mathrm{X}_{1}, \mathrm{P}_{2} \mathrm{X}_{4}$, and $\mathrm{P} 2 \mathrm{X}_{7}$ purinoceptors and ENTPD1, ENPTD2, ENPTD5, ENPTD6, ENPP2, ENPP3, ENPP4, ENPP5, and ENPP6 enzymes. Our findings underscore the utility of genetic immunization for generating highly specific polyclonal and monoclonal antibodies directed against proteins in native conformation (ADAPINCs) $[19,20]$. These antibodies are valuable tools for assessing the expression levels of the native protein by immunofluorescence analyses and flow cytometry, i.e., assays in which antipeptide antibodies often fail. The antibodies described here provide useful tools for further characterization of the structure and function of these purinoceptors and ecto-enzymes.

Acknowledgements Part of this work was supported by grant No310/6-1 from the Deutsche Forschungsgemeinschaft to FKN and FH. SA was the recipient of a stipend from the Fondation pour la Recherche Medical. We thank Christiane Beig, Inga Heinsohn, and Fenja Braasch for excellent technical assistance. FKN and FH designed and supervised this study with essential contributions by SA and MS. SM and CJ performed the experiments shown in Figs. 2, 3,4 .

Conflict of interest statement The Haag and Koch-Nolte labs receive a share of the revenues from commercial sales of the antibodies described here by Analytical Services North, Hamburg.

\section{References}

1. Bodin P, Burnstock G (2001) Purinergic signalling: ATP release. Neurochem Res 26:959-969

2. la Sala A, Ferrari D, Di Virgilio F et al (2003) Alerting and tuning the immune response by extracellular nucleotides. J Leukoc Biol 73:339-343

3. Zimmermann H (2000) Extracellular metabolism of ATP and other nucleotides. Naunyn Schmiedebergs Arch Pharmacol 362:299-309

4. Burnstock G (2006) Pathophysiology and therapeutic potential of purinergic signaling. Pharmacol Rev 58:58-86

5. Haag F, Adriouch S, Braß A et al (2007) Extracellular NAD and ATP: partners in immune cell modulation. Purinergic Signalling 3:71-81

6. Di Virgilio F, Chiozzi P, Ferrari D et al (2001) Nucleotide receptors: an emerging family of regulatory molecules in blood cells. Blood 97:587-600

7. North RA (2002) Molecular physiology of P2X receptors. Physiol Rev 82:1013-1067

8. Ralevic V, Burnstock G (1998) Receptors for purines and pyrimidines. Pharmacol Rev 50:413-492

9. Burnstock G, Williams M (2000) P2 purinergic receptors: modulation of cell function and therapeutic potential. J Pharmacol Exp Ther 295:862-869

10. Khakh BS, Burnstock G, Kennedy C et al (2001) International union of pharmacology. XXIV. Current status of the nomenclature and properties of $\mathrm{P} 2 \mathrm{X}$ receptors and their subunits. Pharmacol Rev 53:107-118

11. Zimmermann H, Beaudoin AR, Bollen M et al (2000) Proposed nomenclature for two novel nucleotide hydrolysing enzyme families expressed on the cell surface. In: L Vanduffel, R Lemmens (eds) Ecto-ATPases and related ectonucleotidases. Masstricht, Shaker Publishing B.V., pp 1-8

12. Ivanenkov VV, Meller J, Kirley TL (2005) Characterization of disulfide bonds in human nucleoside triphosphate diphosphohydrolase 3 (NTPDase3): implications for NTPDase structural modeling. Biochemistry 44:8998-9012

13. Stefan C, Jansen S, Bollen M (2005) NPP-type ectophosphodiesterases: unity in diversity. Trends Biochem Sci 30:542-550

14. Vial C, Roberts JA, Evans RJ (2004) Molecular properties of ATP-gated P2X receptor ion channels. Trends Pharmacol Sci $25: 487-493$

15. Khakh BS, North RA (2006) P2X receptors as cell-surface ATP sensors in health and disease. Nature 442:527-532

16. Robson SC, Sévigny J, Zimmermann H (2005) The E-NTPDase family of ectonucleotidases: structure function relationships and pathophysiological significance. Purinergic Signalling 2:409-430

17. Gijsbers R, Ceulemans H, Stalmans W et al (2001) Structural and catalytic similarities between nucleotide pyrophosphatases/phosphodiesterases and alkaline phosphatases. J Biol Chem 276:13611368

18. Zalatan JG, Fenn TD, Brunger AT et al (2006) Structural and functional comparisons of nucleotide pyrophosphatase/phosphodiesterase and alkaline phosphatase: implications for mechanism and evolution. Biochemistry 45:9788-9803

19. Tang DC, DeVit M, Johnston SA (1992) Genetic immunization is a simple method for eliciting an immune response. Nature 356:152-154

20. Koch-Nolte F, Duffy T, Nissen M et al (1999) A new monoclonal antibody detects a developmentally regulated mouse ecto-ADPribosyltransferase on $\mathrm{T}$ cells: subset distribution, inbred strain variation, and modulation upon $\mathrm{T}$ cell activation. $\mathrm{J}$ Immunol 163:6014-6022 
21. Seman M, Adriouch S, Scheuplein F et al (2003) NAD-induced T cell death: ADP-ribosylation of cell surface proteins by ART2 activates the cytolytic P2X7 purinoceptor. Immunity 19:571-582

22. Koch-Nolte F, Glowacki G, Bannas P et al (2005) Use of genetic immunization to raise antibodies recognizing toxin-related cell surface ADP-ribosyltransferases in native conformation. Cell Immunol 236:66-71
23. Adriouch S, Dubberke G, Diessenbacher P et al (2005) Probing the expression and function of the $\mathrm{P} 2 \mathrm{X} 7$ purinoceptor with antibodies raised by genetic immunization. Cell Immunol 236:72-77

24. Diessenbacher P, Bartels K, Koch-Nolte F, et al (2003) T-cell survival regulator LKLF is not involved in inappropriate apoptosis of diabetes-prone BBDP rat T cells. Ann N Y Acad Sci 1010:548-551 